\title{
Fast and Slow Spreading Ridges: Structure and Hydrothermal Activity, Ultramafic Topographic Highs, and $\mathrm{CH}_{4}$ Output
}

\author{
Henri Bougault, 'Jean-Luc Charlou, 1 Yves Fouquet, 1 Hubert D. Needham, ${ }^{1}$ Nathalie Vaslet, ${ }^{1}$ \\ Pierre Appriou, ${ }^{2}$ Philippe Jean Baptiste, ${ }^{3}$ Peter A. Rona, ${ }^{4}$ Leonid Dmitriev, ${ }^{5}$ and Sergei Silantievs
}

\begin{abstract}
Different parts of the world ridge system have quite different morphologies, which reflect different constructional processes. It appears that hydrothermal circulation at all spreading centers is an important exchange process between the ocean and the newly formed oceanic crust. This hydrothermal circulation may vary according to morphology and crustal composition and may also affect ridge constructional processes. The TAG $\left(26^{\circ} \mathrm{N}\right)$ and Snake Pit $\left(23^{\circ} \mathrm{N}\right)$ hydrothermal sites on the MidAtlantic Ridge (MAR) display $\mathrm{Mn} / \mathrm{CH}_{4}$ ratios in overlying seawater similar to those of nonsedimented East Pacific Rise sites, i.e., about $0.2 \mathrm{mo} / \mathrm{L}$. In contrast, large methane anomalies with very low $\mathrm{Mn} / \mathrm{CH}_{4}$ ratios of $0.005 \mathrm{~mol} / \mathrm{L}$ are associated with ultramafic topographic highs near $15^{\circ} \mathrm{N}$, close to the axis and on ultramafic walls of the rift valley. The association of ultramafic bodies and $\mathrm{CH}_{4}$ anomalies in seawater indicates active serpentinization processes. $\mathrm{CH}_{4}$ is produced during serpentinization according to the Fisher Tropsch reaction (Charlou et al., 1991). Many ultramafic rock assemblages have been sampled on the MAR away from fracture zones, in particular by the Deep Sea Drilling Project. Changes of mechanical properties and of density of uplifted deep material in the accreting plate boundary zone caused by serpentinization may play an important role in the construction of slow spreading ridges.
\end{abstract}

\section{INTRODUCTION}

The oceanic lithosphere is constructed by a combination of tectonic extension and magma generation. These two interacting processes create the almost continuous, linear, mid-oceanic ridge system. The large differences in the morphologies of axial zones of the ridge seem to be grossly controlled by the spreading rate [e.g., Macdonald, 1982]. The typical morphology of many fast spreading ridges is smooth and domelike in cross section, with a small axial graben (0-50 m deep, $300 \mathrm{~m}$ wide). Structural discontinuities of different orders along the axis define linear segments from ten to hundreds of kilometers long [Macdonald et al., 1988]. Slow spreading ridges have generally rougher topography with more complex structure and more variable geometry along their axes. Slow spreading ridges typically have a deep axial valley $(2000 \mathrm{~m})$ with inner floor widths that range from a few to more than $10 \mathrm{~km}$ [e.g., Needham and Francheteau, 1974; Needham and Carré, 1990; Sempéré et al., 1990].

Hydrothermal circulation at, or close to, the ridge axis was inferred from recognition of deep seawater or brine temperature measurements in the Red Sea [Bruneau et al., 1953; Neumann and Densmore, 1959; Degens and Ross, 1969] and of a metalliferous component in the sediments of the East Pacific Rise [Skornyakova, 1965]. Lister [1972] attributed low values of conductive heat flow measured on the Juan de Fuca Ridge to convective cooling by circulation

\footnotetext{
${ }^{1}$ Département Géosciences Marines, IFREMER, Centre de Brest, Plouzane, France.

2Département de Chimie, Faculté des Sciences, Université de Bretagne Occidentale, Brest, France.

${ }^{3}$ Laboratoire de Géochimie Isotopique, Centre d'Etudes Nucléaires de Saclay, Gif sur Yvette, France.

${ }^{4}$ Atlantic Oceanographic and Meteorological Laboratory, National Oceanic and Atmospheric Administration, Miami, Florida.

${ }^{5}$ Vernadsky Institute of Geochemistry, Moscow.

Copyright 1993 by the American Geophysical Union.

of seawater. Evidence of hydrothermal circulation venting on the seafloor was obtained in 1977-1979 with observations of low-temperature vents and associated biota on the Galapagos spreading center [Corliss et al., 1979], of relict sulfide mounds [Francheteau et al., 1979], and of high-temperature vents [Spiess et al., 1980] at the East Pacific Rise axis. Hydrothermal mounds close to the Galapagos rift zone [Honnorez et al., 1981] and a helium plume emanating from the East Pacific Rise [Lupton and Craig, 1981] were subsequently reported. On the slow spreading Mid-Atlantic Ridge (MAR), some evidence of hydrothermal activity was gathered in 1974 at $36^{\circ} \mathrm{N}$ [ARCYANA, 1975; Hoffert et al., 1978]; the TAG hydrothermal field has been known since 1972 on the evidence of its manganese deposits and associated lowtemperature discharge [Rona, 1976; Rona et al., 1984]. Additional evidence of hydrothermal circulation on this ridge was obtained by detecting manganese [Klinkhammer et al., 1985], methane [Charlou et al., 1988], and physical [Speer, 1989] anomalies in the water column of the rift valley and from direct observations of high-temperature vents at the TAG site $\left(26^{\circ} \mathrm{N}\right)$ [Rona et al., 1986] and south of the Kane fracture zone $\left(23^{\circ} \mathrm{N}\right)$ [ Leg 106 Scientific Shipboard Party, 1986].

Based on the newly discovered $\mathrm{CH}_{4}$ outputs associated with ultramafic outcrops on the MAR [Charlou et al., 1988; Bougault et al., 1990c; Charlou et al., 1991a; Rona et al., 1992], we emphasize similarities but also large differences observed in the nature of hydrothermal activity at morphologically contrasting fast and slow spreading ridges.

\section{Hydrothermal Activity and Magmatic-Tectonic Cycles along a Fast Spreading Ridge: The EAST PACific Rise}

The first-order segmentation of the ridge, defined by major topographic lows along the axis, is either controlled by fracture zones or by overlapping spreading centers (OSCs) [Macdonald et al., 1984; Schouten et al., 1985]. Early interpretations postulated that most of the hydrothermal 


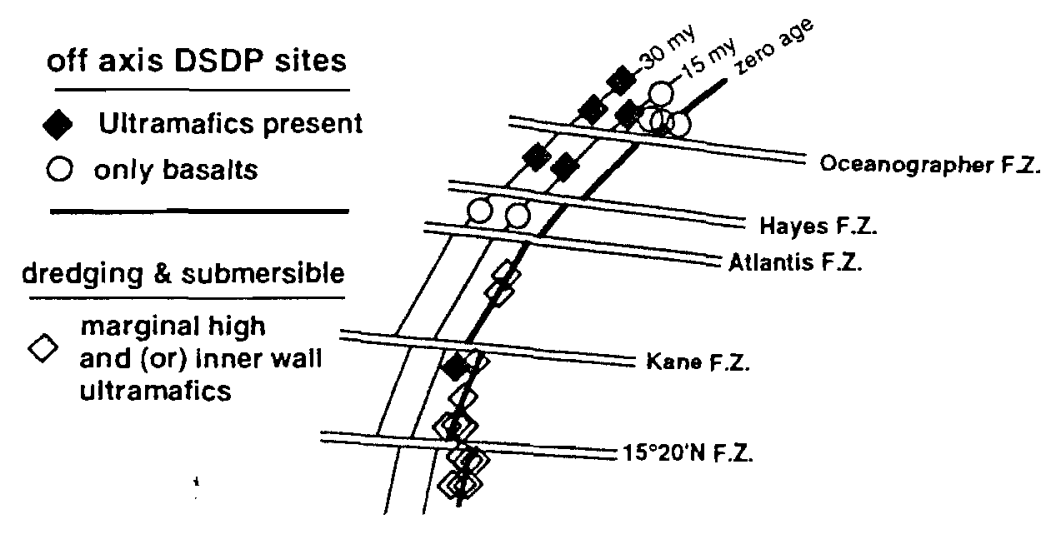

Fig. 1. Sketch of the MAR between about $15^{\circ} \mathrm{N}$ and Azores Triple Junction showing locations of ultramafic rocks recovered by the DSDP (solid lozenges) or by dredging or submersible surveys (open lozenges). Crustal ages (zero to

$30 \mathrm{Ma}$ ) are shown to the west of the MAR axis. DSDP sites where only basalts were recovered are indicated by an open circle.

activity along fast spreading ridges is related to this segmentation and is located on topographic highs centered in the middle of major ridge segments [Francheteau and Ballard, 1983]. From physical measurements in seawater, Baker and Massoth [1986] obtained the first picture of a hydrothermal plume. The distribution of geothermal fields along the East Pacific Rise (EPR) were deduced from towing a thermistor array [Crane et al., 1988]. Images from the high-resolution side scan sonar synthetic aperature radar [Vaslet et al., 1989] and a continuous record of hydrothermal activity (temperature, $\mathrm{Mn}$, and $\mathrm{CH}_{4}$ ) along $100 \mathrm{~km}$ of the axis of the EPR from the topographic low at $11^{\circ} 30^{\prime} \mathrm{N}$ to the topographic high at $13^{\circ} 30^{\prime} \mathrm{N}$ [Bougault et al., 1990b,c] show that hydrothermal activity on the EPR is correlated with subsegmentation defined by discontinuities from first to fourth order and further correlated with the presence of a well-developed graben. Similar information, by using the Argo remote operated vehicle (ROV), was gathered on the EPR near $9^{\circ} \mathrm{N}$ [Haymon et al., 1991].

A narrow, continuous, partially molten zone, inferred from seismic data to be present along the axis, disappears under the OSCs, i.e., OSCs at $12^{\circ} 37^{\prime} \mathrm{N}$ and $12^{\circ} 54^{\prime} \mathrm{N}$ [Avedik and Géli, 1987; Detrick et al., 1987; Toomey et al., 1990]. This molten zone is potentially a continuous source of magma along the axis and a driving force for potential hydrothermal activity. Close to the topographic high at the middle of a major segment of the EPR $\left(11^{\circ} 20^{\prime} \mathrm{N}-14^{\circ} 30^{\prime} \mathrm{N}\right)$ the segmentation in morphology and in hydrothermal activity was clearly illustrated by two subsegments: the segment located north of the OSC at $12^{\circ} 54^{\prime} \mathrm{N}$ has almost no graben and low methane and manganese signals in the water column, whereas the subsegment between $12^{\circ} 37^{\prime} \mathrm{N}$ and $12^{\circ} 54^{\prime} \mathrm{N}$ presents a 50 -m-deep graben and very high hydrothermal signals [Vaslet et al., 1989; Bougault et al., 1990 c]. In addition, even within a subsegment, hot hydrothermal areas can be preferentially associated with recent magma eruptions represented by lava lakes (i.e., $12^{\circ} 48^{\prime} \mathrm{N}$ ) [Gente et al., 1984; Hékinian et al., 1984].

This suggests that the following conditions prevail. Faulting and fissuring create high permeability which favors seawater and fluid circulation. Lava lakes are recorded by quenched lava roofs (about $15 \mathrm{~cm}$ thick), generally collapsed and lying on the basaltic seafloor, and by pillars which record the different lava levels of the lakes. These features are indicative of tectonic activity and magma supply in a way which allows the graben to be maintained. Some of the hot dykes can reach the surface and provide magma to lava lakes. There is a steep temperature gradient between the edge of the hot dike and the adjacent cool basement: at the boundary between the hot dyke and the cool basement, thermal effects should produce fissures and microfissures creating a high-permeability zone. Since the dyke is still at some hundreds of degrees Celsius, fiuids could be driven up to the surface through this high-permeability, high-temperature boundary zone. The above observations and this tentative interpretation would account for the emplacement of hydrothermal sources not only on fissures and faults (including at the edge of the graben) but also at the site of lava lakes.

The observations made at $13^{\circ} \mathrm{N}$ and at $9^{\circ} \mathrm{N}$ suggest that intense hydrothermal discharges are intermittent along ridge axes. Modelled heat flow budgets at the ridge crest do not permit permanent and intense hydrothermal discharges all along the axis [Converse et al., 1984]. Along the $100 \mathrm{~km}$ of ridge axis explored during the HYDROFAST cruise [Bougault et al., 1990b], only two intense hot hydrothermal areas (at $12^{\circ} 44^{\prime} \mathrm{N}$ and $12^{\circ} 48^{\prime} \mathrm{N}$ ) were detected along a $17-\mathrm{km}$ long subsegment (from the $12^{\circ} 37^{\prime} \mathrm{N}$ to $12^{\circ} 54^{\prime} \mathrm{N}$ OSCs).

\section{active Serpentinization on Slow Spreading Rudges: The Mid-AtLantic RIDGe}

The nature of hydrothermal activity at the two well studied TAG and Snake Pit sites on the slow MAR is similar to that on non-sedimented sites of the fast spreading EPR (e.g., $21^{\circ} \mathrm{N}$ and $13^{\circ} \mathrm{N}$ ) using as criteria deposit paragenesis and mineralogy [Fouquet et al., 1988; Thompson et al., 1988] and fluid compositions [Campbell et al., 1988a, b; Charlou et al., 1991b; Donval et al., 1989; Jean Baptiste et al., 1991; Michard et al., 1984]. In particular, $\mathrm{Mn}, \mathrm{CH}_{4}$, and $\mathrm{Mn} / \mathrm{CH}_{4}$ ratios [Charlou et al., 1991b] have similar values to those found along the EPR. Despite the similarity of the two known active hydrothermal sites on the MAR with nonsedimented EPR hydrothermal sites, $\mathrm{CH}_{4}$ outputs, with very low $\mathrm{Mn} / \mathrm{CH}_{4}$ ratio in seawater, have been discovered to be associated with ultramafic exposure at several sites of the axial region of the MAR [Bougault et al., 1990c; Charlou et $a l ., 1991 b$ ]; they reveal a different aspect of exchanges between the ocean and the lithosphere.

The occurrence of serpentinized ultramafic rocks on the MAR was initially thought to be almost restricted to fracture 
zones [Bonatti, 1976; Bonatti and Honorez, 1976], although there was debate about whether or not fracture zones expose a deep, continuous layered section of the oceanic crust [Francheteau et al., 1976]. Some scientists argued that ultramafic rocks drilled at site 334 during leg 37 of Deep Sea Drilling Project (DSDP) [Aumento et al., 1977] were located in an unknown fracture zone. Ultramafics also were drilled at site 495 during leg 45 [Melson et al., 1978] and sites 556, 558 and 561 during leg 82 [Bougault et al., 1985; Michael and Bonatti, 1985] (Figure 1). Evidence of "zero age" ultramafics on the MAR away from fracture zones has been commonly reported [Aumento and Loubat, 1971; Bonatti et al., 1975; Detrick et al., 1990; Juteau et al., 1990; Zonenshain et al., 1989; Dick, 1989]. Brooks et al. [1992] reported on the occurrence of basalts, gabbros, and highly serpentinized peridotites on a "landslide" of the rift valley wall, between the Kane and Atlantis fracture zones. In the axial region of the MAR in the area of $15^{\circ} \mathrm{N}$, close to or well away from the $15^{\circ} 20^{\prime} \mathrm{N}$ Fracture Zone, ultramafics were documented in many places by Rona et al. [1987], Bougault et al. [1990a] and by several Russian cruises during 1989-1990, as summarized by Silantiev et al. [1991]. The recent diving cruise FARANAUT 15N (1992), part of the French-U.S. program FARA, better documented previous ultramafic and gabbroic rocks on the walls of the rift valley (see Figure 2).

The topographic high " $N$ " is part of the first inner step of the eastern wall of the MAR at $15^{\circ} 37^{\prime} \mathrm{N}, 28 \mathrm{~km}$ north of the $15^{\circ} 20^{\prime} \mathrm{N}$ fracture zone intersection (Figure 2). A dredge haul on the summit of high " $N$ " recovered mainly harzburgites with some dunites and gabbros [Bougault et al., 1990a; Cannat et al., 1992]. Most of the samples are mylonitized. Many of the serpentinized peridotites have gabbroic veins altered to chlorite, talc, and other secondary minerals. Two Nautile dives during the FARANAUT 15N diving expedition in 1992 have confirmed the ultramafic nature of the topographic high "N." We use the term ultramafic topographic high (UTH) to designate this type of axial feature.

Serpentinized ultramafic rocks (harzburgites and dunites) and gabbros were also dredged at two different sites on the western wall of the rift valley, at $15^{\circ} 30^{\prime} \mathrm{N}$ and at $15^{\circ} 37^{\prime} \mathrm{N}$ at the same latitude as UTH "N" [Silantiev et al., 1991]. Several dives (FARANAUT $15 \mathrm{~N}$ cruise) have since confirmed that the western wall of the rift valley is composed of ultramafics (harzburgite and dunite) and of gabbros. Gabbros and serpentinized dunites are also present on the outer part of the eastern wall $\left(46^{\circ} 31^{\prime} \mathrm{W}\right.$, Figure 2$)$. The inner floor of the rift valley between $46^{\circ} 40^{\prime}$ and $46^{\circ} 36^{\prime} \mathrm{N}$ is covered with pillow lavas.

The first hydrocast performed in this area in 1988, which recorded $60 \mathrm{~nL} / \mathrm{L}$ of methane, was located between UTH $\mathrm{N}$ and the eastern wall (Figure 2). Methane concentrations in seawater sampled by the submersible in 1992, about $1 \mathrm{~m}$ above the seafloor, are much higher almost everywhere on both walls of the valley (commonly $400 \mathrm{~nL} / \mathrm{L}$ ), whereas methane concentrations are close to the seawater background $(5 \mathrm{~nL} / \mathrm{L})$ on the basaltic inner floor of the valley.

The eastern intersection of the rift valley with the $15^{\circ} 20^{\prime} \mathrm{N}$ $\mathrm{FZ}$ is shown in Figure 3. A prominent topographic high, designated " $\mathrm{A}$ " (centered at $15^{\circ} 04.5^{\prime} \mathrm{N}-44^{\circ} 59^{\prime} \mathrm{W}$ ) forms the inside corner high of the rift valley/transform fault intersection. Topographic highs " $B$ " and " $C$ " on the edge of the fracture zone (Figure 3 ) are inferred to be older analogs of topographic high "A." The distance between these marginal highs, which lie along the southern boundary of the fracture
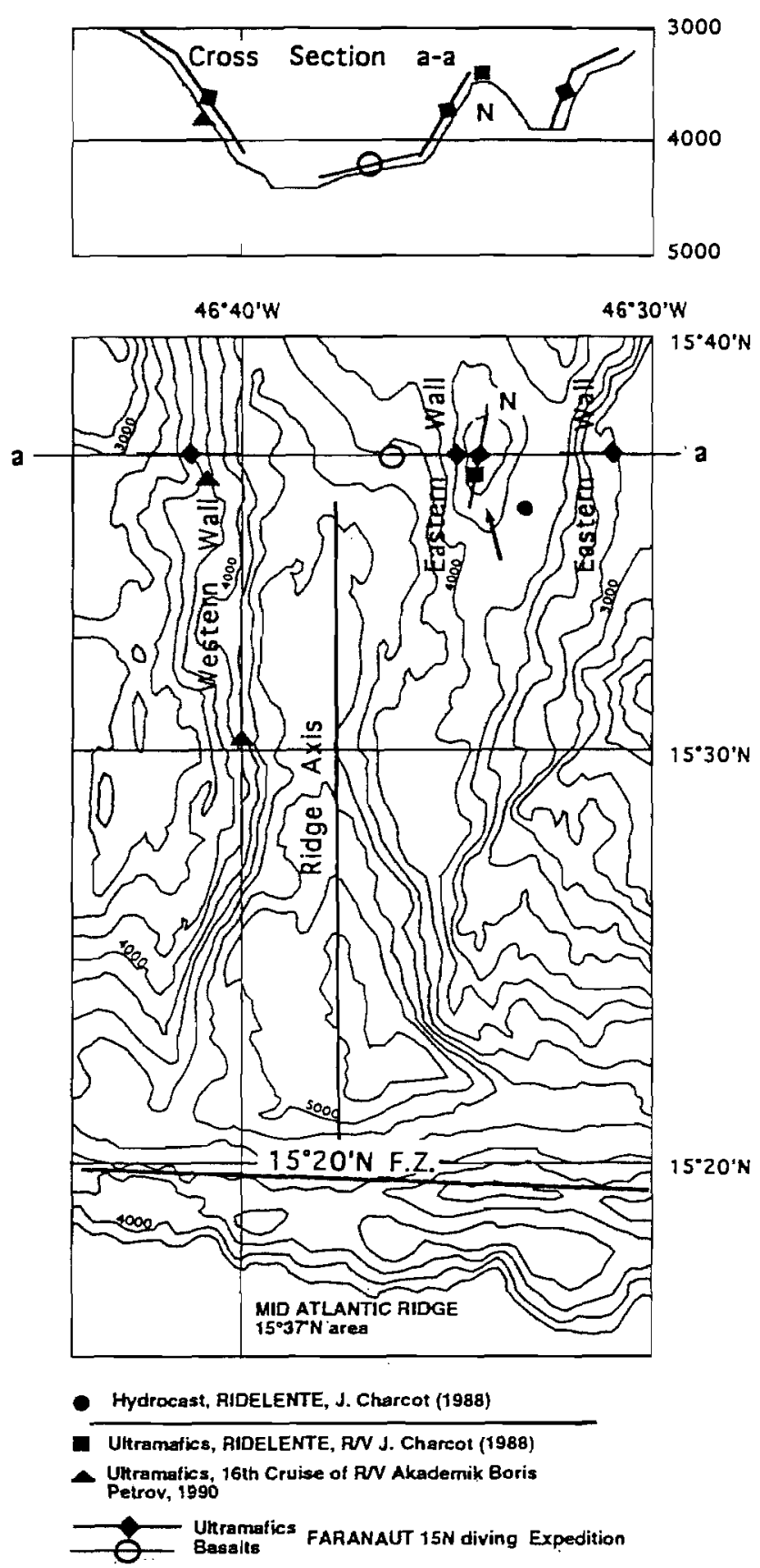

Fig. 2. MAR axis north of the $15^{\circ} 20^{\prime} \mathrm{N}$ Fracture Zone. At $15^{\circ} 37^{\prime} \mathrm{N}$, about $28 \mathrm{~km}$ north of the $15^{\circ} 20^{\prime} \mathrm{N}$ F.Z., the western wall is located at $46^{\circ} 40^{\prime} \mathrm{W}$ : the eastern wall shows two steps, the inner one at $46^{\circ} 37^{\prime} \mathrm{W}$ and the outer one at $46^{\circ} 31^{\prime} \mathrm{W}$. The structural high " $N$ " (indicated by the arrow) forms the inner step of the eastern wall. Cross section a-a at $15^{\circ} 37^{\prime} \mathrm{N}$ summarizes seafloor topography and nature from various cruises: RIDELENTE [Bougault et al., 1990 a], cruise 16 of the R/V Akademik Boris Petrov [Silantiev et al., 1991] and FARANAUT 15N diving expedition (1992). Both walls at $15^{\circ} 37^{\prime} \mathrm{N}$, including high " $\mathrm{N}$," are composed of ultramafics (gabbros are also present, mainly on the outer eastern wall); basaltic pillows compose the inner floor of the valley. Methane output was first documented by one hydrocast between UTH " $N$ " and the outer eastern wall and then further documented by samples taken by the submersible, close to the seafioor.

zone valley, is about $7.5 \mathrm{~km}$, which suggests a periodicity of about 750,000 years (spreading rate: $1 \mathrm{~cm} / \mathrm{yr}$ ) for their construction. Three dredges [Silantiev et al., 1991] on topographic high "A" recovered ultramafic rocks, including one 


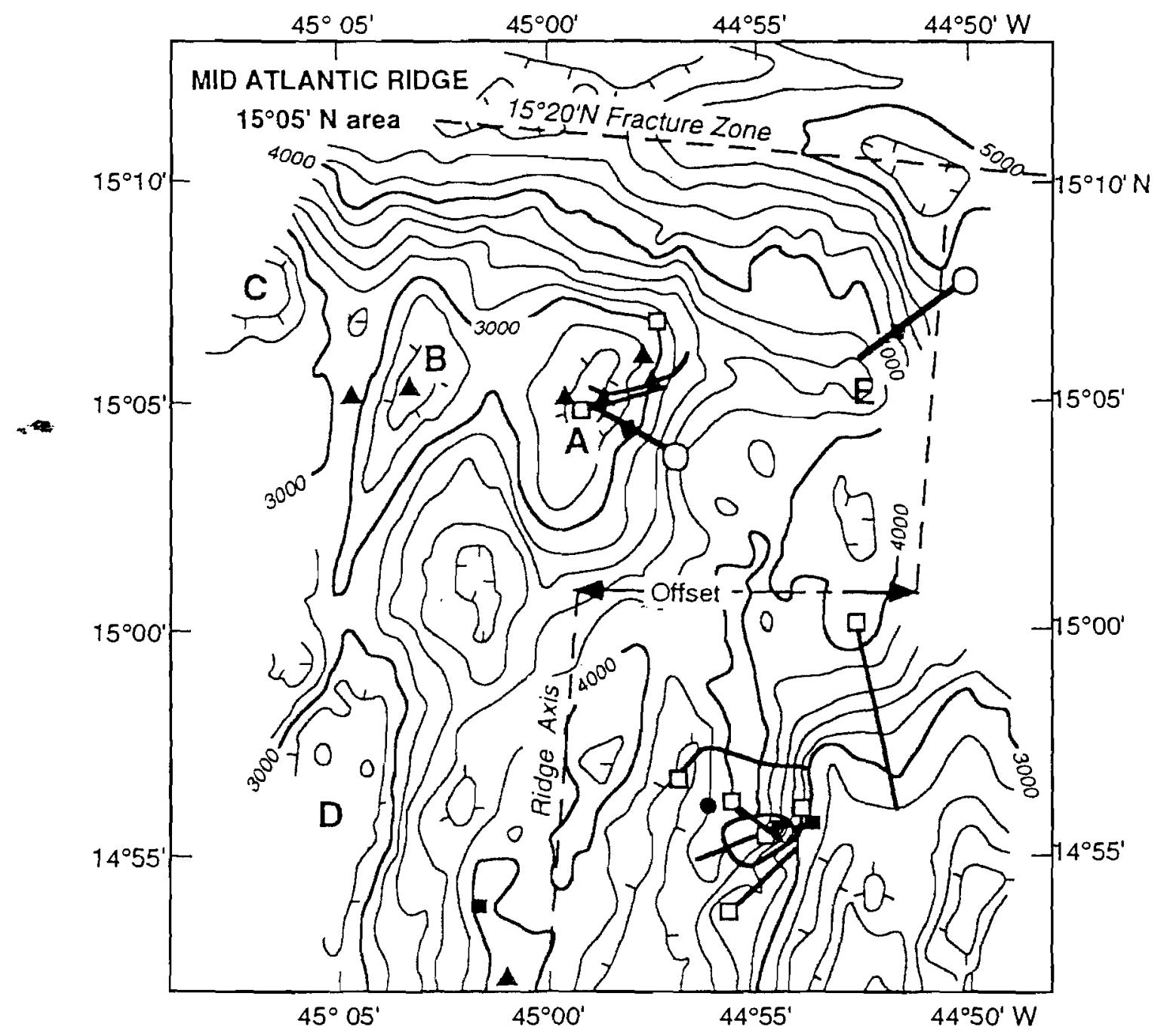

: bydrocasts, RN Researcber (1984)

- : bydrocast, RIDELENTE, RN J. Charcol (1988)

7 : Ultramafics, RN Researcher (1984)

A : Ultramafics, 16th Cruise of R/V Akademik Boris Petrov (1990)

: Ultramafics, FARANAUT 15N diving cruise (1992)

0 : Basalts, FARANAUT 15N diving cruise (1992)

Fig. 3. MAR axis south of the $15^{\circ} 20^{\prime} \mathrm{N}$ Fracture Zone. The main western wall is at $45^{\circ} 05^{\prime} \mathrm{W}$ and the main eastern

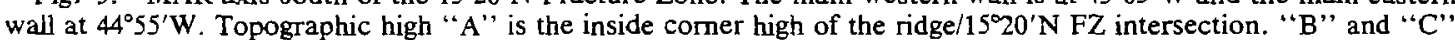
are inferred to be older analogs of "A," on the southem edge of the fracture zone. The ridge axis is offset at latitude $15^{\circ} \mathrm{N}$. "E" is thought to be the newly developing inside coner at the ridge $/ 15^{\circ} 20^{\prime} \mathrm{N}$ FZ intersection. Basalts are present on the inner floor at the base of " $E$ " and " $A$ "; " $E$," " $A$ " and " $B$ " are composed of ultramafic rocks. Methane output is well documented on " $A$ " (see Figure 5).

dredge on the summit, which is at about the same depth as the tops of adjacent rift mountains. Serpentine sediment containing aragonite needles and other secondary minerals, such as occur on UTH "N," was also sampled. A dredge on topographic high " $B$ " recovered ultramafics. Submersible dives revealed that the eastern flank of " $A$ " consists of ultramafics from base to top. Similarly, ultramafics are present from the inner floor rift valley/transform intersection up to the top of topographic high "E." Ultramafic rocks were previously reported on the eastern wall of the valley at $14^{\circ} 56^{\prime} \mathrm{N}$ [Rona et al., 1987] (Figure 3); they are also present on the western wall at $14^{\circ} 52.5^{\prime} \mathrm{N}$ and $14^{\circ} 49^{\prime} \mathrm{N}$ [Silantiev et al., 1991] and on an inner floor high adjacent to the eastern wall at $14^{\circ} 53^{\prime} \mathrm{N}$ [Dmitriev and Scientific Party, 1985]. The occurrences of these ultramafic rocks at different locations are summarized in a composite cross section of the rift valley in Figure 4.

Several hydrocasts taken in this area recorded large methane anomalies [Bougault et al., 1990c; Charlou et al., 1988, 1991b; Rona et al., 1992]. Interestingly, previous hydrocasts in this area taken in 1984 [Klinkhammer et al., 1985; Rona, 1987] recorded low manganese signals. This low 
manganese to methane ratio was confirmed during subsequent cruises [Charlou et al., 1991b] and the FARANAUT $15 \mathrm{~N}$ diving expedition. Seawater samples collected some meters above the seafioor of UTH A revealed large methane outputs halfway to the top of the high and on its summit (Figure 5) [Charlou et al., 1991b; Rona et al., 1992]. Manganese signals have also been detected at the same locations as methane signals, but the $\mathrm{Mn} / \mathrm{CH}_{4}$ ratio is confimed to be very low. The ratios measured in seawater sampled close to the ultramafic seafloor are the same as the ratio measured from vertical hydrocasts in the water column of this area (Figure 5).

The submersible data confirm that the large methane concentrations in seawater directly associated with ultramafic outcrops are common and suggest that they reflect an active $p$ cess associated with the emplacement of ultramafic crust.

\section{Discussion}

It is now confirmed that some segments of the MAR show large methane (low manganese) outputs. There are three possible origins for this methane: biological, sedimentary, or hydrothermal (including the hydrothermal serpentinization process). Isotopic carbon data would be useful to distinguish between these possible different sources, but insufficient methane available in our water samples precluded analysis. However, a sedimentary source is excluded as this part of the MAR is barren. There is no known biological activity on these axial sites which could account for the large methane production, which is similar to that produced at the surface of the ocean. Instead, these large methane concentrations are clearly related to axial ultramafic structures (they were not recorded over pillow lavas on the inner floor), and the helium anomalies which were detected during FARANAUT $15 \mathrm{~N}$ are correlated with methane anomalies ( $P$. Jean Baptiste, personal communication, 1992). Since methane production through the Fisher Tropsch reaction during serpentinization is well known [Charlou et al., 1991b], we conclude that this process explains at least the major part of the methane anomalies.

$\mathrm{Mn} / \mathrm{CH}_{4}$ ratios are very low compared to ratios near hydrothermal sites located on volcanic structures. It is important to know whether this low $\mathrm{Mn} / \mathrm{CH}_{4}$ signal reflects the characteristics of fluids circulating through ultramafics, as opposed to fluids circulating through volcanic rocks. The residence time of methane in seawater is shorter than that of manganese [Kadko et al., 1990], which would tend to increase, and not to decrease, an initial $\mathrm{Mn} / \mathrm{CH}_{4}$ ratio. In addition, the very high $\mathrm{CH}_{4}$ signals detected close to the bottom on the eastern flank of UTH A (Figure 5) indicate that the fluid output areas are located nearby and thus that the time available to modify the $\mathrm{Mn} / \mathrm{CH}_{4}$ ratio would be short. We conclude that the low $\mathrm{Mn} / \mathrm{CH}_{4}$ ratio detected in seawater in this area does indeed provide a signature of fluid discharge from ultramafic bodies which contrasts with those of fluids sampled at the TAG and Snake Pit sites on the MAR, or on the EPR (Figure 5). Variable ${ }^{3} \mathrm{He} /$ heat ratios from seawater measurements have already been demonstrated to trace variable properties of hydrothermal systems [Lupton et al., 1989]; very different $\mathrm{Mn} / \mathrm{CH}_{4}$ ratios in seawater can also trace differences in hydrothermal systems. The only other reported occurrence of high methane con-
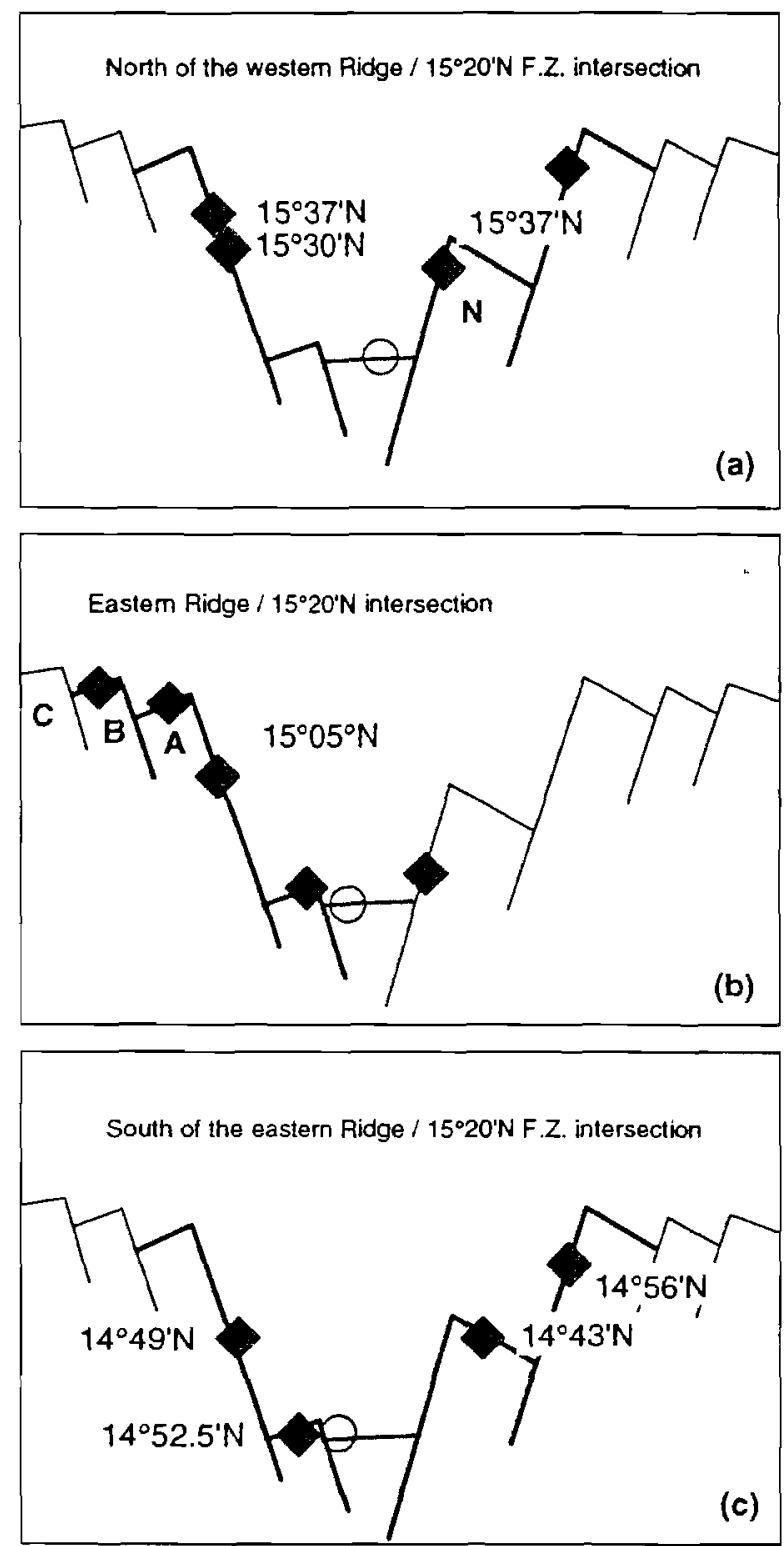

Uitramatics

Basalts

Either from dredging or submersible exploration / sampling

Fig. 4. Locations of ultramafics (solid lozenges) from dredge hauls and submersible dives on three schematic cross sections of the MAR in the area of $15^{\circ} \mathrm{N}$. Basalt pillows are indicated by open circles. Latitudes of sites are indicated.

centrations associated with an ultramafic structure is in the Mariana forearc [Mottl and Haggerty, 1989]: in this case, the fluid temperature is low and the $p \mathrm{H}$ very high (12.5). A high $p \mathrm{H}$ might also be responsible for the low manganese values over MAR ultramafic sites. A high $p \mathrm{H}$ of fluids circulating through ultramafics would result in very low Mn concentrations compared to those found for acidic hydrothermal fuids. Nevertheless, Mn concentrations in fluids controlled by hydroxide precipitation would be so low that they probably would preclude any Mn detection in seawater after dilution; other processes than hydroxide formation should account for mobilizing $\mathrm{Mn}$ in ultramafics in a way that $\mathrm{Mn}$ 


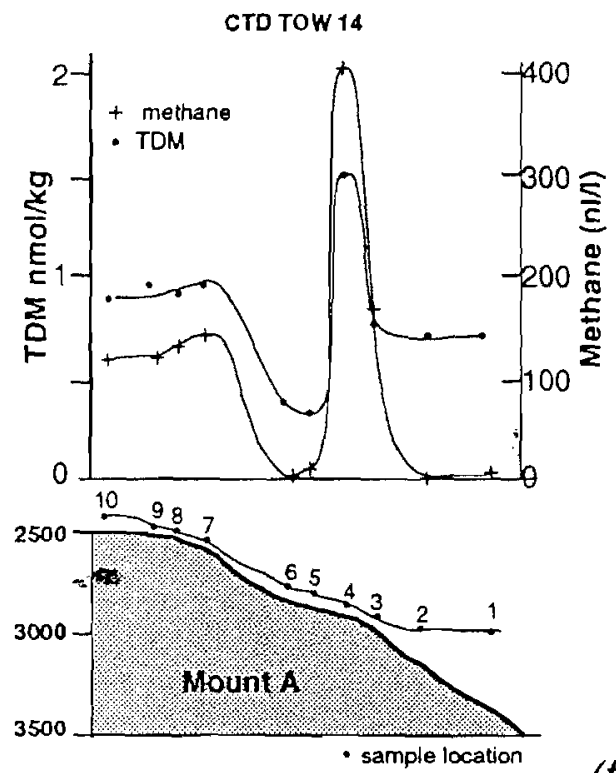

(a)

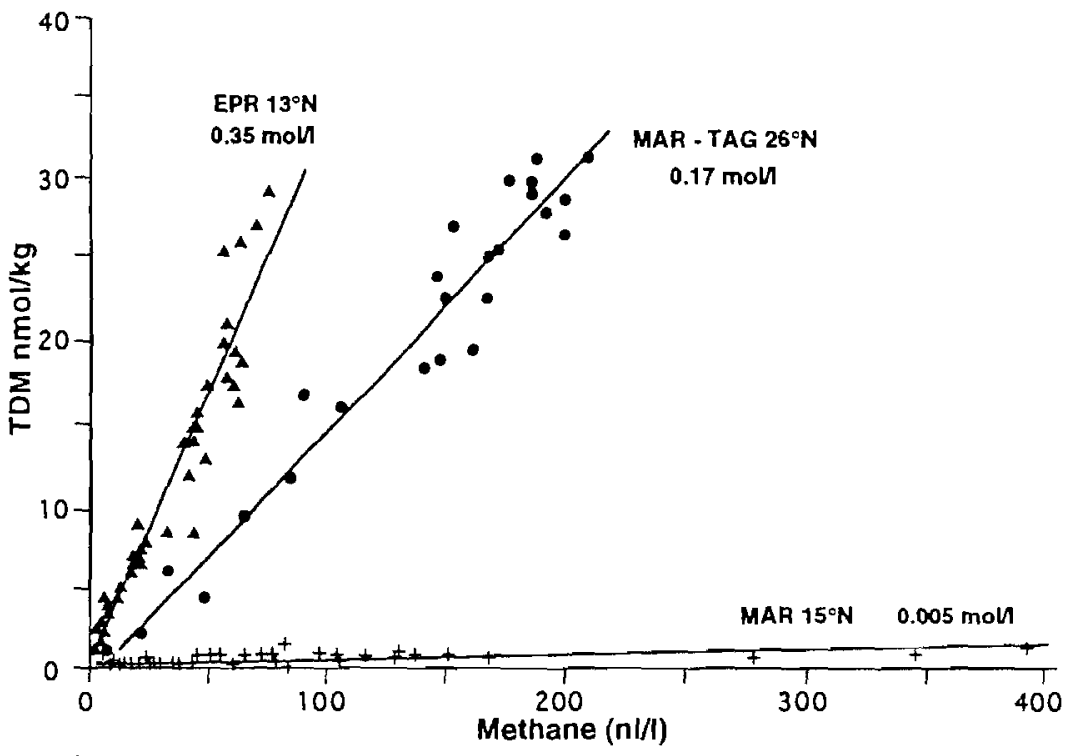

(b)

Fig. 5. (a) Large methane and small manganese outputs from UTH "A" recorded during MAR 88 cruise [Charlou et al., 1991b; Rona et al., 1992]. The lower part shows the locations where seawater samples were taken just a few meters above UTH "A," during an east-west cast. The upper part shows the $\mathrm{CH}_{4}$ and $\mathrm{Mn}$ concentrations above each location. (b) Low $\mathrm{Mn} / \mathrm{CH}_{4}$ ratio at $15^{\circ} \mathrm{N}$ compared to EPR and MAR-TAG sites. The $\mathrm{Mn}$ and $\mathrm{CH}_{4}$ signals are both well visible in Figure $5 a$, but the $\mathrm{Mn} / \mathrm{CH}_{4}$ ratio is much lower on this UTH (and generally over axial ultramafic structures on the MAR) than on hydrothermal sites developing on volcanic structures.

would be low after dilution in seawater, but still detectable and correlated to $\mathrm{CH}_{4}$.

As pointed out by Cann [1979], water/rock ratios may vary from very low at the centers of blocks to very high near the faults or fissures; in consequence, serpentinization should be expected to be heterogeneous at various scales. Since serpentinization is exothermic, this process can produce selfmaintained circulation of low-temperature fluids when and where fissures are present. The degree of serpentinization depends in part on the relative amounts of fissuring and clogging (by neoformed minerals) and does not require an external heat source. This process is still hydrothermal, even if self-produced heat drives the fluids, but it is a quite different process than hydrothermal circulation caused by a direct heat source from a magma chamber. The detection of methane anomalies from $14^{\circ} \mathrm{N}$ to $23^{\circ} \mathrm{N}$ at the depth of the rift mountain summits (well above the valley floor) [Bougault et al., 1990c; Charlou and Donval, this issue] indicates a common, ongoing process along the MAR. In the constructional processes of a slow spreading ridge, serpentinization could have two principal effects: lowering the density of ultramafic rocks and acting as a lubricant facilitating isostatic equilibration. Although lack of knowledge about the geometry and density of the serpentinized bodies poses difficulties, these observations will have to be taken into account in constructing crustal models for the interpretation of gravimetric measurements. Such models confront the problem of the large possible variation of the density of serpentinized bodies; they would be very different according to whether they incorporate a magmatically well supplied or starved ridge crust.

Models have been proposed to explain the interactions between the ridge/transform/ridge boundaries [Fox and Gallo, 1984]. According to Francis [1981], serpentinization is important in accounting for the morphology of slow spreading ridges, involving both transform faults at ridge/ transform intersections and faults parallel to the axis. The recorded depth of microearthquakes $(7 \mathrm{~km})$ on the ridge axis and transform faults [Francis et al., 1978] suggests that seawater penetrates deep into the crust and reaches the uppermost mantle. Francis et al. proposed that most of the serpentinization at a ridge-transform intersection would take place on the old side of the transform. These observations and interpretations by Francis [1981] and by Toomey et al. [1988] should be considered in light of the results discussed here (axial/marginal UTH, occurrence of ultramafics on both walls of the rift valley). Serpentinization is most likely to affect the young lithosphere created close to ridge/transform intersections, associated with and probably contributing to the periodic construction (about every 750,000 years) of inside corners highs such as " $A$," " $B$," " $C$ " (Figure 3 ). It may also affect young lithosphere away from the immediate area of rift/fracture zone intersections, associated with and probably contributing to the formation of marginal highs such as UTH " $N$ " and to the formation of rift valley walls (western and eastern walls at the same latitude as UTH "N") (Figures 2 and 4). Another site where ultramafics are present on inner walls and on structures adjacent to inner walls and where a $\mathrm{CH}_{4}$ anomaly was also detected [Charlou et al., 1991a] occurs south of the $15^{\circ} 20^{\prime} \mathrm{N}$ Fracture Zone (FZ), at $14^{\circ} 43^{\prime} \mathrm{N}$ (Figure 4 ).

The relative uplift of ultramafic blocks may occur along normal faults, or along low-angle detachment faults during amagmatic tectonic extension as proposed by Karson et al. [1987]. Serpentinization (and methane output) can take place during both processes. The low-angle detachment model is asymmetric and predicts that one wall comprises ultramafics uplifted along the detachment fault, whereas the other wall is 
made of basaltic crust. However, in the examples reported here, the opposing walls of the rift valley consist of ultramafics (Figure 4). The best documented case at $15^{\circ} 37^{\prime} \mathrm{N}$ is summarized in Figure 2. At this locality, methane anomalies up to $400 \mathrm{~nL} / \mathrm{L}$ are detected on both western and eastern ultramafic walls, indicative of active processes.

For isostatic reasons, a magmatic extension with little production of magma necessarily implies uplift of mantle material at some stage. This process is not likely to be synchronous all along a segment and is probably affected by local tectonics. The size of the ultramafic blocks involved is typically $10 \mathrm{~km}$ long, $5 \mathrm{~km}$ wide, as suggested by UTHs "N," "A," and "B." Topographic highs " $C$ " (part of the transverse ridge) and " $D$ " (along the rift mountains, Figure 3) may be other examples, but their ultramafic nature is not documented.

Althơgh created in a dominantly extensional regime, inside corner ultramafic highs are formed in the very specific mechanical context of a fracture zone/ridge axis intersection. In this setting, exchanges between seawater and UTH inside corners may be effective both at the ridge axis and in the adjacent part of the fracture zone. The comment made earlier on gravimetric anomalies and the occurrence of serpentinized blocks still apply in this context, but serpentinization of these structures could be more efficient than elsewhere along the rift valley and could contribute to their marked elevation.

\section{CONCLUSIONS}

The results discussed in this paper show and confirm several relationships between hydrothermal activity and structures of the ridge axis.

On a fast spreading ridge, hydrothermal activity is selectively distributed with respect to the segmentation of the axis, as defined by discontinuities of different orders such as OSCs, devals, and even smaller discontinuities revealed by high-resolution side scan sonar. Hydrothermal activity is important on subsegments where tectonic extension has recently predominated over magma production, leading to a well-developed graben (i.e., $50 \mathrm{~m}$ deep). During such tectonic extension, magma production does occur in several places but forms only lava lakes and does not overflow the graben. Active hydrothermal sites are mostly located in this context.

On a slow spreading ridge, $\mathrm{CH}_{4}$ hydrothermal signals with low $\mathrm{Mn} / \mathrm{CH}_{4}$ ratios are detected in the median valley. Hydrothermal outputs at active hydrothermal sites (Snake Pit and TAG) lying on volcanic structures have relatively high $\mathrm{Mn} / \mathrm{CH}_{4}$ ratios, similar to those on fast spreading ridges.

On the MAR, important $\mathrm{CH}_{4}$ signals with a low $\mathrm{Mn} / \mathrm{CH}_{4}$ ratio occur in the water column near axial/marginal serpentinized UTHs and ultramafic inner walls of the rift valley. This water anomaly reflects a different type of hydrothermal activity. The hydrothermal signal tends to be strongest near transform-ridge intersections and is also present near the summits of the neighboring rift mountains away from intersections. These signals, which are quite strong in the water column at some locations (i.e., at $16^{\circ} 38^{\circ} \mathrm{N}$ ) and are always detected close to ultramafic seafloor, reflect ongoing serpentinization. Because serpentinization lowers rock density, it can contribute, at least in part, to the formation of uplifted structures and to the formation of adjacent rift mountains. Close to transform-ridge intersections, the conjunction of transform faults and of normal faults along the axis enhances fluid circulation and wallrock reactions. Enhanced serpentinization at these locations may play a role in the formation of elevated inside corner highs and their older counterparts along the edges of fracture zones.

The well-documented occurrence of ultramafic rocks at the axis of the MAR (symmetrically on both walls in many places) and the active serpentinization as inferred from $\mathrm{CH}_{4}$ water anomalies provide a perspective on the formation of the upper crust of a slow spreading ridge that differs in some important respects from the classic model of a simple layered oceanic crust.

Acknowledgments. Most of the recent results discussed in this paper were obtained during cruises of the $\mathrm{R} / \mathrm{V}$ Jean Charcot (HYDROFAST, 1986; RIDELENTE, 1988), the R/V Akademik Boris Petrov (second cruise, 1985), NOAA Ship Researcher (1984), and NOAA Ship Oceanographer (MAR 88, 1988). Dredging during cruises 12 and 16 of the R/V $A$ Boris Petrov $(1989,1990)$, cruise 3 of the R/V A. Nikolai Strakov (1989), cruise 12 of the R/V A. Antares (1990) documented occurrences of ultramafics in the area of $15^{\circ} \mathrm{N}$. The recent FARANAUT 15N diving expedition ( $R / V$ l'Atalante and submersible Nautile) brought further complementary information on the ocean floor. These cruises reflect a cooperative program supported and conducted by IFREMER (France), NOAA (USA), and Vernadsky Institute of Geochemistry (Russia). The captains and crews of these research vessels are acknowledged for their support at sea during these cruises. FARANAUT $15 \mathrm{~N}$ cruise was planned as a part of the FARA French-U.S. program to study the MAR between $15^{\circ} \mathrm{N}$ and the Azores. We thank K. Crane and T. J. Barret for helpful reviews.

\section{REFERENCES}

ARCYANA, Transform fault and rift valley from bathyscaph and diving saucer, Science, 190, 108-116, 1975.

Aumento, F., and H. Loubat, The Mid-Atlantic Ridge near $45^{\circ} \mathrm{N}$, serpentinized ultramafic intrusions, Can. J. Earth Sci., 8, 631$663,1971$.

Aumento, F., et al., Site 334, Initial Rep. Deep Sea Drill. Proj., 37, 201-338, 1977.

Avedik, F., and L. Géli, Single-channel seismic reflection data from the East Pacific Rise axis between latitude $11^{\circ} 50$ and $12^{\circ} 54^{\prime} \mathrm{N}$, Geology, 15, 857-860, 1987.

Baker, E. T., and G. J. Massoth, Hydrothermal plume measurements: A regional perspective, Science, 234, 980-982, 1986.

Bonatti, E., Serpentinite protrusions in the ocean crust, Earth Planet. Sci. Lett., 32, 107-113, 1976.

Bonatti, E., and J. Honnorez, Sections of the Earth's crust in the equatorial Atlantic, J. Geophys. Res., 81, 4104-4116, 1976.

Bonatti, E., J. Honnorez, P. Kirst, and F. Radicali, Metagabbros from the Mid-Atlantic Ridge at $6^{\circ} \mathrm{N}$ : Contact-hydrothermaldynamic metamorphism beneath the axial valley, J. Geol., 83, 61-78, 1975.

Bougault, H., et al., Sites 556,558 and 560, Initial Rep. Deep Sea Drill. Proj., 82, 61-112, 127-214, 233-243, 1985.

Bougault, H., et al., Campagne RIDELENTE: Structure de la dorsale atlantique, hétérogénéité du manteau et hydrothermalisme, Oceanol. Acta, vol. spéc. 10, 366-381, 1990a.

Bougault, H., et al., Campagne HYDROFAST: Etudes quantitatives de l'activité hydrothermale sur la ride-est pacifique a $13^{\circ}$ nord, Oceanol. Acta, vol. spéc. 10, 276-291, $1990 \mathrm{~b}$.

Bougault, H., J. L. Charlou, Y. Fouquet, and H. D. Needham, Activité hydrothermale et structure axiale des dorsales EstPacifique et médio-Atlantique, Oceanol. Acta, vol. spéc. 10 , 199-207, 1990c.

Brooks, B., D. K. Smith, J. R. Cann, M. E. Dougherty, J. Lin, S. Spencer, C. J. MacLeod, E. McAllister, R. A. Pascoe, and J. A. Keeton, Tobi deep-towed side scan mosaics of spreading seg- 
ments at the MAR $\left(24^{\circ}-30^{\circ} \mathrm{N}\right)$, Eos Trans. $A G U, 73(43)$, Fall Meeting suppl., 568, 1992.

Bruneau, L., L. G. Jerlov, and F. Koczy, Report of the Swedish Deep Sea Expedition XIX-XXX, 1953

Campbell, A. C., T. S. Bowers, C. I. Measures, K. K. Falkner, M. Khadem, and J. M. Edmond, A time series of vent fluid compositions from $21^{\circ} \mathrm{N}$, East Pacific Rise $(1979,1981,1983)$ and the Guaymas Basin, Gulf of Califomia (1982, 1985), J. Geophys. Res., $93,4537-4549,1988 a$.

Campbell, A. C., M. R. Palmer, G. P. Klinkhammer, T. S. Bower, J. M. Edmond, J. R. Lawrence, J. F. Casey, S. E. Humphris, P. A. Rona, and J. A. Karson, Chemistry of hot springs on the Mid-Atlantic Ridge: TAG and MARK'sites, Nature, 335, 514-519, $1988 b$.

Cann, J. R., Metamorphism in the ocean crust, in Deep Drilling Results in the Atlantic Ocean: Ocean Crust, Maurice Ewing Ser. volo 2 , edited by M. Talwani, C. G. Harrison and D. E. Hayes, pp. 230-238, AGU, Washington, D. C., 1979.

Cannat, M., D. Bideau, and H. Bougault, Serpentinized peridotites and gabbros in the Mid-Atlantic Ridge axial valley at $15^{\circ} 37^{\prime} \mathrm{N}$ and $16^{\circ} 52^{\prime} \mathrm{N}$ : Primary mineralogy, microstructures and hydrothermal evolution, Earth Planet. Sci. Lett., 109, 87-106, 1992.

Charlou, J. L., and J. P. Donval, Hydrothermal methane venting between $12^{\circ} \mathrm{N}$ and $26^{\circ} \mathrm{N}$ along the Mid-Atlantic Ridge, J. Geophys. Res., this issue.

Charlou, J. L., L. Dmitriev, H. Bougault, and H. 'D. Needham, Hydrothermal $\mathrm{CH} 4$ between $12^{\circ} \mathrm{N}$ and $15^{\circ} \mathrm{N}$ over the Mid-Atlantic Ridge, Deep Sea Res., 35, 121-131, 1988.

Charlou, J. L., H. Bougault, P. Appriou, P. Jean-Baptiste, J. Etoubleau, and A. Birolleau, Water column anomalies associated with hydrothermal activity between $11^{\circ} 40^{\prime}$ and $13^{\circ} \mathrm{N}$ on the East Pacific Rise: Discrepancies between tracers, Deep Sea Res., 38, 569-596, $1991 a$.

Charlou, J. L., H. Bougault, P. Appriou, T. Nelsen, and P. A. Rona, Different TDM/CH4 hydrothermal plume signatures: TAG site a $26^{\circ} \mathrm{N}$ and serpentinized ultrabasic diapir at $15^{\circ} 05^{\prime} \mathrm{N}$ on the MidAtlantic Ridge, Geochim. Cosmochim. Acta, 55, 3209-3222, $1991 b$.

Converse, D. R., H. D. Holland, and J. M. Edmond, Flow rates in the axial hot springs of the East Pacific Rise $\left(21^{\circ} \mathrm{N}\right)$ : Implications for the heat budget and the formation of massive sulfide deposits, Earth Planet. Sci. Lett., 69, 159-175, 1984.

Corliss, J. B., J. Dymond, L. I. Gordon, J. M. Edmond, R. P. Von Herzen, R. D. Ballard, K. Green, D. Williams, A. Bainbridge, K. Crane, and T. H. Van Andel, Submarine thermal springs on the Galapagos Rift, Science, 203, 1073-1083, 1979.

Crane, K., F. Aikman, and J. P. Foucher, The distribution of geothermal fields along the East Pacific Rise from $13^{\circ} 10^{\prime}$ to $8^{\circ} 20^{\prime} \mathrm{N}$ : Implications for deep seated origins, Mar. Geophys. Res., 9, 211-236, 1988.

Degens, E. T., and D. A. Ross, Hot Brines and Heavy Metal Deposits in the Red Sea, 600 pp., Springer-Verlag, New York, 1969.

Detrick, R., P. Buhl, J. Mutter, E: Vera, J. Orcutt, J. Masden, and $\mathrm{T}$. Brocher, Multichannel seismic imaging of a crustal magma chamber along the East Pacific Rise, Nature, 326, 35-41, 1987.

Detrick, R., et al., Site 670, Proc. Ocean Drill. Program, Initial Rep., 106/109, 203-237, 1990.

Dick, H. J. B., Abyssal peridotites, very slow spreading ridges and ocean ridge magmatism, in Magmatism in the Ocean Basin, edited by A. D. Saunders and M. J. Norris, Geol. Soc. Spec. Publ. London, 42, 71-105, 1989.

Dmitriev, L., and Scientific Party, Cruise report of the 2nd cruise of the R/V Akademik Boris Petrov, Vemadsky Inst. of Geochem., Moscow, 1985

Donval, J. P., D. Grimaud, M. Stievenard, H. Bougault, J. L. Charlou, P. Jean Baptiste, A. Michard, and C. Mevel, Chemistry of hot springs on the Snake Pit, Mid-Atlantic ridge, Terra Cognita, 1, 325, 1989.

Fouquet, Y., G. Auclair, P. Cambon, and J. Etoubleau, Geological setting and mineralogical and geochemical investigations on sulfide deposits near $13^{\circ} \mathrm{N}$ on the East Pacific Rise, Mar. Geol., 84, $145-178,1988$.

Fox, P. J., and D. G. Gallo, A tectonic model for Ridge-TransformRidge plate boundaries: Implication for the structure of the oceanic lithosphere, Tecronophysics, 104, 205-242, 1984.
Francheteau, J., and R. D. Ballard, The East Pacific Rise near $21^{\circ} \mathrm{N}$, $13^{\circ} \mathrm{N}$ and $20^{\circ} \mathrm{S}$ : Inferences for along strike variability of axial processes of the Mid-Ocean Ridge, Earth Planet. Sci. Lett., 64 , 93-116, 1983.

Francheteau, J., P. Choukroune, R. Hekinian, X. Le Pichon, and H. D. Needham, Oceanic fracture zones do not provide deep sections in the crust, Can. J. Earth Sci., 13, 1223-1235, 1976.

Francheteau, J., et al., Massive deep sea sulfide deposits discovered on the East Pacific rise, Nature, 277, 523-528, 1979.

Francis, T. J., Serpentinization faults and their role in the tectonics of slow spreading ridges, J. Geophys. Res., 86, 11,616-11,622, 1981.

Francis, T. J., I. T. Porter, and R. C. Liwall, Microearthquakes near the eastern end of St. Paul's fracture zone, Geophys. J.R. Astron. Soc., 53, 201-217, 1978.

Gente, P., J. M. Auzende, H. Bougault, and M. Voisset, Variabilité morphotectonique le long de la dorsale Est-Pacifique entre $11^{\circ}$ et $13^{\circ} \mathrm{N}$. Résultats préliminaires de la campagne Géocyarise 2 (submersible CYANA), C.R. Acad. Sci., 299, 1337-1342, 1984.

Haymon, R. M., D. J. Formari, M. H. Edwards, S. Carbotte, D. Wright, and K. C. Macdonald, Hydrothermal vent distribution along the East Pacific Rise crest $\left(9^{\circ} 09^{\prime}-9^{\circ} 54^{\prime} \mathrm{N}\right)$ and its relationship to magmatic and tectonic processes on fast-spreading midocean ridges, Earth Planet. Sci. Lett., 104, 513-534, 1991.

Hékinian, R., M. Fevrier, F. Avedik, P. Cambon, J. L. Charlou, H. D. Needham, J. Raillard, J. Boulegue, L. Merlivat, A. Moinet, S. Manganini, and J. Lange, East Pacific Rise Near $13^{\circ}$ : Geology of new Hydrothermal Fields, Science, 219, 1321-1324, 1983.

Hékinian, R., V. Renard, and J. L. Cheminée, Hydrothermal deposits on the East Pacific Rise near $13^{\circ} \mathrm{N}$ : Geological setting and distribution of active sulfide chimneys, in Hydrothermal Processes at Seafloor Spreading Centers, edited by P. Rona et al., pp. 571-574, Plenum, New York, 1984.

Hoffert, M., A. Perseil, R. Hékinian, P. Choukroune, H. D. Needham, J. Francheteau, and X. Le Pichon, Hydrothermal deposits sampled by diving saucer in transform fault " $\mathrm{A}$ " near $37^{\circ} \mathrm{N}$ on the Mid-Atlantic Ridge, Famous area, Oceanol. Acta, 1 , $73-86,1978$.

Honnorez, J., et al, Hydrothermal mounds and young ocean crust of the Galapagos: Preliminary Deep Sea Drilling results, leg 70, Geol. Soc. Am. Bull., 92, 457-472, 1981.

Jean Baptiste, P., J. P. Charlou, M. Stievenard, J. P. Donval, H. Bougault, and C. Mevel, Helium and methane measurements in hydrothermal tluids from the Mid-Atlantic Ridge: The Snake Pit site at $23^{\circ} \mathrm{N}$, Earth Planet. Sci. Lett., 106, 17-28, 1991.

Juteau, T., M. Cannat, and Y. Lagabrielle, Serpentinized peridotites in the upper oceanic crust away from transform zones: A comparison of the results of previous and ODP legs, Proc. Ocean Drill. Program, Sci. Results, I06/109, 303-308, 1990.

Kadko, D. C., N. D. Rosenberg, J. E. Lupton, R. W. Collier, and M. D. Lilley, Chemical reaction rates and entrainment within the Endeavour Ridge hydrothermal plume, Earth Planet. Sci. Lett., $99,315-335,1990$

Karson, J. A., et al., Along axis variations in sea-floor spreading in the MARK area, Nature, $328,681-685,1987$.

Klinkhammer, G. D., P. A. Rona, M. Greaves, and H. Elderfield, Hydrothermal manganese plume in the MAR rift valley, Nature, 314, 727-731, 1985.

Leg 106 Scientific Shipboard Party, Mid-Atlantic bare-rock drilling and hydrothermal vents, Nature, 321, 14-15, 1986.

Lister, C. R. B., On the thermal balance of a mid-ocean ridge, Geophys. J. R. Astron. Soc., 26, 515-535, 1972.

Lonsdale, P., Overlapping rift zones at $5.5^{\circ} \mathrm{S}$ offset of the East Pacific Rise crest, J. Geophys. Res., 88, 9393-9406, 1983.

Lupton, J. E., and H. Craig, A major helium-3 source at $15^{\circ} \mathrm{S}$ on the East Pacific Rise, Science, 214, 13-18, 1981.

Lupton, J. E., E. T. Baker, and G. J. Massoth, Variable ${ }^{3} \mathrm{He} /$ heat ratios in submarine hydrothermal systems: Evidence from two plumes over the Juan de Fuca Ridge, Nature, 337, 161-164, 1989.

Macdonald, K. C., Mid-ocean ridges: Fine scale tectonic, volcanic and hydrothermal processes within the plate boundary zone, Annu. Rev. Earth Planet. Sci, 10, 155-190, 1982.

Macdonald, K. C., J. C. Sempere, and P. J. Fox, The East Pacific Rise from the Siquieros to Orozco fracture zones: Along-strike continuity of the neovolcanic zone and structure and evolution of 
overlapping spreading centers, J. Geophys. Res., 89, 6049-6069, 1984.

Macdonald, K. C., P. J. Fox, L. J. Perram, M. F. Eisen, R. M. Haymon, S. P. Miller, S. M. Carbotte, M. H. Cormier, and A. N. Shor, A new view of the mid-ocean ridge from the behaviour of ridge-axis discontinuities, Nature, 335, 217-225, 1988.

Melson, W. G., et al., Site 395, Initial Rep. Deep Sea Drill. Proj., 45, 131-264, 1978.

Michael, P. J., and E. Bonatti, Petrology of ultramafic rocks from sites 556, 558 and 560 in the North Atlantic, Initail Rep. Deep Sea Drill. Proj., 82, 523-528, 1985.

Michard, A., F. Albarède, G. Michard, J. F. Minster, J. L. Charlou, and N. Tan, Chemistry of the solutions from the $13^{\circ} \mathrm{N}$ East Pacific Rise hydrothermal site, Earth Planet. Sci. Lett., 67, 297-307, 1984

Mottl, M. J., and J. A. Haggerty, Upwelling of $\mathrm{Cl}$ poor $\mathrm{C}$ rich waters through a serpentine seapount, Mariana Forearc: ODP leg 125, Eos Tra $A G U, 70,1382,1989$.

Needham, H. D., and D. Carré, Transit PABRE, Oceanol. Acta, spec. vol. 10, 343-347, 1990.

Needham, H. D., and J. Francheteau, Some characteristics of the rift valley in the Atlantic Ocean near $36^{\circ} 48^{\prime} \mathrm{N}$, Earth Planet. Sci. Lett., 22, 29-43, 1974

Neumann, A. C., and C. D. Densmore, Oceanographic data from the Mediterranean Sea, Gulf of Aden and Indian Ocean, Rep. 62, p. 2, Woods Hole Oceanogr. Inst., Woods Hole, Mass., 1959.

Prinzhofer, A., E. Lewin, and C. J. Allègre, Stochastic melting of the marble cake mantle: Evidence from local study of the East Pacific Rise at $12^{\circ} 50^{\prime} \mathrm{N}$, Earth Planet. Sci. Lett., 92, 189-206, 1989

Rona, P. A., Patem of hydrothermal deposition: Mid-Atlantic Ridge crest at latitude $26^{\circ} \mathrm{N}$, Mar. Geol., 21, M59-M66, 1976.

Rona, P. A., Hydrothermal mineralization at slow-spreading centers: The Atlantic model, Mar. Min., 6, 1-7, 1987.

Rona, P. A., G. Thompson, M. J. Mottl, J. A. Karson, W. J. Jenkins, D. Graham, M. Mallette, K. Von Damm, and J. M. Edmond, Hydrothermal activity at the Trans-Atlantic Geotraverse hydrothermal field, Mid-Atlantic Ridge crest at $26^{\circ} \mathrm{N}$ J. Geophys. Res., 89, 11,365-11,377, 1984

Rona, P. A., G. Klinkhammer, T. A. Nelsen, J. H. Trefry, and H. E.lderfield, Black smokers, massive sulphides and vent biota at the Mid-Atlantic Ridge, Nature, 321, 33-37, 1986.

Rona, P. A., L. Widenfalk, and K. Boström, Serpentinized ultramafics and hydrothermal activity at the Mid-Atlantic Ridge crest near 15N, J. Geophys. Res., 92, 1417-1427, 1987.

Rona, P. A., H. Bougault, J. L. Charlou, P. Appriou, T. A. Nelsen, J. H. Trefry, G. L. Eberhart, A. Barone, and H. D. Needham, Hydrothermal circulation, serpentinization, diapirism and degas ing at a rift valley-fracture zone intersection: Mid-Atlantic Ridge near $15^{\circ} \mathrm{N}, 45^{\circ} \mathrm{W}$, Geology, 20, 783-786, 1992.
Schouten. H., K. D. Klitgord, and J. A. Whitehead, Segmentation of mid-ocean ridges, Nature, 317, 225-226, 1985.

Sempéré, J. C., G. M. Purdy, and H. Schouten, Segmentation of the Mid-Atlantic Ridge between $24^{\circ} \mathrm{N}$ and $30^{\circ} 40^{\prime} \mathrm{N}$, Nature, 344 , 427-431, 1990.

Silantiev, S., H. J. B. Dick, and Scientific Party, Cruise report of the 16th cruise of the R/V Akademik Boris Petrov, Vemadsky Inst. of Geochem., Moscow, 1991.

Skornyakova, I. S., Dispersed iron and manganese in Pacific Ocean sediments, Int. Geol. Rev., 7, 2165-2174, 1965.

Speer, K. G., An Atlantic hydrothermal plume: Trans-Atlantic Geotraverse (TAG) area, Mid-Atlantic Ridge crest near $26^{\circ} \mathrm{N}, J$. Geophys. Res., 94, 13,879-13,893, 1989.

Spiess, F. N., et al., East Pacific Rise: Hot springs and geophysical experiments, Science, 207, 1421-1433, 1980.

Thompson, G., S. E. Humphris, B. Schroeder, M. Sulanowska, and P. A. Rona, Active vents and massive sulfides at $26^{\circ} \mathrm{N}$ (TAG) and $23^{\circ} \mathrm{N}$ (Snakepit) on the Mid-Atlantic Ridge, Can. Mineral., 26, 697-711, 1988.

Toomey, D. R., S. C. Salomon, and G. M. Purdy, Microearthquakes beneath the median valley of the Mid-Atlantic Ridge near $23^{\circ} \mathrm{N}$ : Tomography and tectonics, J. Geophys. Res., 93, 9093-9112, 1988.

Toomey, D. R., G. M. Purdy, S. C. Solomon, and W. S. D. Wilcock, The tridimensional seismic velocity structure of the East Pacific Rise near latitude $9^{\circ} 30^{\prime} \mathrm{N}$, Nature, 347, 639-645, 1990.

Vaslet, N., Y. Fouquet, M. Voisset, and H. Bougault, Apports des images du sonal latéral SAR à la cartographie d'une zone hydrothermale de la ride Est Pacifique, C.R. Acad. Sci., 309, 267-273, 1989.

Zonenshain, L. P., M. I. Kumin, A. P. Lisitsin, and B. V. Bogdanov, Tectonics of the Mid-Atlantic rift valley between the TAG and MARK areas $\left(24-26^{\circ} \mathrm{N}\right)$, Tectonophysics, 159, 1-23, 1989 .

P. Appriou, Département de Chimie, Fac. Sciences, Av. Le Gorgeu, 29200 Brest, France

P. J. Baptiste, Lab. Géochimie Isotopique, DSM/DPh'SPER, CEA, CEN Saclay, 91191 Gif sur Yvette, France.

H. Bougault, J. L. Charlou, Y. Fouquet, H. D. Needham, and N. Vaslet, IFREMER, Centre de Brest, DRO/GM, 29280 Plouzané, France.

L. Dmitriev and S. Silantiev, Vernadsky Institute of Geochemistry, 47A Vorobiovscoe Shosse, Moscow W334, Russia.

P. Rona, AOML, NOAA, 4301 Rickenbacker Causeway, Miami, FL 33149.

(Received July 9, 1991; revised February 5, 1993; accepted March 1, 1993.) 